\title{
First love simplicity: A systemic-functional perspective study of Karina Del Campo's Do You Remember Our Love?
}

\author{
1Sugeng Purwanto and 2Idha Nurhamidah* \\ ${ }^{1}$ Universitas Stikubank, Indonesia \\ ${ }^{2}$ Universitas Islam Sultan Agung, Indonesia \\ *Corresponding Author \\ Email: idhanurhamidah@unissula.ac.id
}

\begin{abstract}
The current study aims at exploring the intended meaning and structure of a poem entitled 'Do You Remember Our Love?' written by a poet, (C) Karina Del Campo (2009) in both interpretational and systemic functional perspectives. In the former, the poem was examined interpretatively in order to find out the possible stance of the poet; meanwhile the later was an analytical representation of systemic functional grammar in the framework of construing the three domains of meanings: ideational, interpersonal and textual in order to arrive at the field, the tenor and the mode of the discourse. It turns out that the poem is a reflection of a woman's feeling (the poet's) toward her ex-boyfriend-finely described in a repeated style of the major clause, supported and elaborated in several minor clauses. The poet tries very hard to ignite her ex-boyfriend's love memories with her and to possibly invite him to reunite even though it seems to be a mission impossible. The poem has both social and psychological impacts on the poet herself and the readers in a wider scope.
\end{abstract}

Keywords: interpretational perspective, systemic functional perspective, discourse

Received:

Revised:

31 May 2018

27 August 2018

Accepted:

Published:

30 August 2018

31 August 2018

\section{INTRODUCTION}

Literature, of a poetry genre to be exact, does not decay over time. It may, though, be enjoyed by means of different media. In the past, a poet might have to read his or her poem loudly for the audience to listen with full heart. In Indonesia, we are familiar with the name of W.S Renda, the greatest Indonesian poet of all time used to read out (or better to say 'act out') his poems to hypnotize the audience who would, in turn, become hysteric in response to the poem being acted out.

Along with the development of literacy where most people can read, they can do lips-read poems for themselves to enjoy literary works within the poetic genre. Anyone with theatrical skills may also read out poems written by famous poets with two possible objectives: (1) to enjoy the beauty of the poem, and (2) to learn the moral values that it may have, as it is commonly known that character can be built through poems to be read or listened to. As of this time, poems can be products of literary industry that can generate a lot of money since it can be distributed in a wider scope of sales. 
Academically speaking, poetry has become a core subject in the department of literature. The students are taught to appreciate, analyze poems based on a standard theory of poetic analysis. In addition, they are also supposed to acknowledge the poet by describing his or her highlighted works in an attempt to better appreciate the poet's products. In this case, the students enjoy analyzing poems in terms of rhyme to see the beauty of the poem; content to see the moral value.

The underlying problem of the current study is that, to the best of the researchers' knowledge, nowadays students pay less attention to the poems of the old generation, commenting that the English is too difficult. In other words, they do not like to bother themselves with old or middle English vocabulary complexity. Therefore they turn to poems of contemporary forms with contemporary poets. This is understandable since contemporary poems may directly reflect the students' own lives. Furthermore, poems can be approached not only from the theory of poetic analysis but also from different disciplines, such as functional grammar or discourse analysis.

A recent study (Purwanto, 2017b) proved that a poem entitled The Hug written by Tess Gallagher was able to be analyzed using an approach generated from discourse study by means of functional grammar analytical framework. The analysis focused on discourse formation within a particular discursive practice. The current study focuses on content analysis on the basis of lexico-grammatical framework. In other words, the poem will be analyzed in terms of how words with semantic entities are constructed on basis of syntactic engineering to achieve the intended meanings.

The research questions of the current study can be formulated as (1) How are words syntactically constructed to achieve the ideational meaning of the poem toward the field of the discourse? (2) How are words syntactically constructed to achieve the interpersonal meaning of the poem toward the tenor of the discourse? (3) How are words syntactically constructed to achieve the textual meaning of the poem toward the mode of the discourse?

Despite the current research dealing with the study of poem viewed from linguistics perspectives, it is necessary to review the position of English in Indonesia as the research is Indonesia-based, and therefore, to proceed the study in a stern positioning toward the real fact in the field (Letters Study Program of faculty of Language and Cultural Studies) in which the current study is conducted.

A controversial issue with respect to the study of English as a foreign language (EFL) in Indonesia is attributed to the shifting paradigm of the terms 'foreign language'. In the past (Fadhillah, 2017), by foreign language is meant that it is not used as a formal or instructional language at school or college. Rather, it is simply a course of study to open up the students' horizon of thinking to know passively a little bit of English. However, in this digital era, whether you like it or not, EFL has to be taught covering the four language skills-listening, speaking, reading and writing. Every high school leaver is expected to be able to carry on simple exchanges in English; though the reality still turns otherwise. 
It is commonly argued that English as a foreign language is not used as a medium of communication in a discursive practice in the society. Rather, it is only taught at school as one of the school subject aimed at equipping the students with basic communicative competence in the four language skills (listening, speaking, reading and writing) though in practice reading has been very much emphasized. However, as it has been touched upon that the concept of a foreign language has been changing over time, it is necessary to review historically the changing concept of a foreign language.

In Dutch colonialization, as(Fadhillah, 2017)quoted in (Purwanto, 2017a) elaborates, it is surprising that a graduate of MULO (SMP level) had got a considerably good English proficiency. It was logical since the system of education was very good and only rich people could manage to study in MULO. Nevertheless, it is not fair to compare the present condition with that of the past. Now, except a graduate of the English Department, a college graduate may not be able to carry on simple Exchanges in English (Purwanto, 2017a). It is argued that the English is focused on reading comprehension skill.

At national level, the government of RI has set a 'language policy' in the world of education, in which it is an obligation to use bahasa Indonesia as a medium of instruction from early education (PAUD)through college level as further strengthened through nationalist movements, fought for the imposition of Indonesian (BI) as the language of unity throughout the country. As an explicit plan, language policy in Indonesia is stipulated in the country's 1945 Constitution, in which the status of BI as a national and official language and the vernacular languages being recognized was clearly stated and elaborated. As the heart of Indonesia's language policy, the 1945 Constitution, Chapter $\mathrm{XV}$, provides a guideline for linguistic unity through the adoption of $\mathrm{BI}$ as the only national and official language, and linguistic diversity via the maintenance of the diverse local languages(Idris, 2014); (Simanjuntak, 2009);(Paauw, 2009); (Ho \& Wong, 2000).

However, it is argued (Purwanto, 2017a)English is used for all subjects related to language. This is not a problem because in the 1st semester, students are equipped with four (4) basic English skills 'performative Spoken English' with the weight of 10 SKS (Liana, Andraini, \& Mariana, 2016). In the 2nd semester, (Purwanto, 2017a)the students start learning the core subjects that force students to use English as the language of academic (instructional), such courses: Introduction to Linguistics and introduction to English Literature. In both these courses of English shall be used in the presentation of materials, textbooks, and evaluation (mid and final) semester, to name only few.

Theoretically speaking, there are three genres of literary works, namely (1) prose genre, (2) drama genre and (3) poetry genre, each of which has special distinctive characteristics which differ from one genre to another.

Of the three genres of literary works, poetry genre belongs to the most difficult and completed subject of studies. Many students refuse to do research on poetry genre due to lack of information with respect to the value of 
poems which actually is a means of expressing 'selves' involving complexity of mind in a compact way. It is still fresh in our mind how poems manage to be used as a social criticism against undemocratic governments. Poets may be chased by the authority due to their critical commentaries against un-equality of treatment of the marginalized societies.

Normally, a piece of poetry is analyzed or approached intrinsically in terms of theme, meter, structure, rhyme, type, imagery, period(Electricka.com, n.d.)

In addition, a poem can also be related to an external discipline, as literarily termed as extrinsic analysis, such as psychology, sociology, politics, economy, etc. Both intrinsic and extrinsic approaches are meant to construe the meaning of a piece of poem, including the purpose or rationale of the poet in writing the poem as such.

Still another approach to analyzing a poem is to employ a linguistic analytical framework of Functional grammar-that is a kind of grammar proposed by Halliday's perspectives of language functionality.

This study employs functional grammar analytical framework to analyze a piece of poem. It has been theorized (Halliday, Matthiessen, \& Halliday, 2014) that language is used to make meanings-ideationally, interpersonally and textually. In the analysis of ideational meaning, the focus is on transitivity and circumstances in response to what is being talked about. Secondly, the interpersonal meaning is construed through the analysis of mood. Finally, the textual meaning deals with the thematic progression of the text.

The three analyses of meanings as above yields (1) field of the discourse, (2) tenor of the discourse and (3) mode of the discourse. Meanwhile the three domains of meanings (Ideational, Interpersonal and Textual meanings) belong to meta-functions of language. In practice, the three meta-functions of language apply at the same time (simultaneously). For example, the language form "No Smoking" carries three meta-functions, namely (1) the ideational meaning or field of the discourse is a prohibition of smoking, (2) the interpersonal meaning or tenor of the discourse is that it is a formal restriction of non-smoking area intended for public viewing-distant relationship between participants (3) the textual meaning or mode of the discourse is that the text was written, adopting the standard form of notice-direct, level of phrase, easy to understand.

Such a short form of text can be analyzed in a macro term without parsing each word into clauses. It can be therefore known directly on the first sight. However, for longer texts, such as speeches, short stories, news items, the case is quite otherwise. The analyst must go into a micro-details, as described as (1) the text must be segmented into major and minor clauses, (2) each clause must be parsed into words for further analysis, (3) ideational meaning can be known from the analysis of transitivity, consisting of participants, circumstances, and verb process, (4) interpersonal meaning is analyzed in terms of mood and residue in which the mood constitutes subject and the finite verb, and the residue consists of the rest, and (5) Textual 
meaning is analyzed in terms of the thematic progression of the text in order to arrive at the genre of the text.

(Ariadi, 2017) employed the discourse by utilizing third space to encourage students' better performance. It investigated teaching and learning process reflected in character teacher of Mr McCourt Teacher Man and Mr Keating Dead Poets Society; so that the interconnection was then within those proses in accordance with educational theory of 'A taxonomy for learning, teaching, and assessing.'

It has been touched above with respect to approaches to poetry analysis. The point is that the current study attempts to unfold a poem, making use of functional grammar in order to define the three poetic meta-functions. Even if it is possible, the beauty of the poem was left untouched with one aim in mind, to describe the poem in terms of ideational, interpersonal and textual entities.

With the knowledge of the three metafictional entities, line by line, the poem can be unfolded in order to find out the core meaning of the poem by mean of which to interpret it for a wider context of comprehension, especially the intended meaning of the poem.

The ideational meaning of a poem will yield what the poem is all about, something like the topic or the theme as normally practiced by the literary analysts. Meanwhile, the interpersonal meaning deals with how the poet treats the readers in terms of the emotional relations. Furthermore, the textual meaning deals with how the poem is fabricated to cater for the intended meaning. The three meta-functions of language are interwoven to create 'meaning' in such a way that the goal of the text (poem) is thereby achieved.

\section{METHOD}

The current study belongs to an exploratory research (Suharsimi, 2006) investigating a poem entitled Do You Remember Our Love? written by (Campo, 2009). Instead of employing intrinsic or/and extrinsic approach to analyzing a poem, this research makes use of functional grammar to construe the three domains of meanings: ideational, interpersonal and textual. The unit of analysis in this study involves lines in the poem, how each line at word level are ideationally, interpersonally and textually constructed. Analysis of each line in the three domains of meaning will yield field, tenor and mode of the discourse on the basis of which meanings can be construed. The first love poem written in 2009 which was actually downloaded from webpage (Campo, 2009) and is displayed fully in the appendix. Each line in the poem is analyzed in a descriptive mode in terms of ideational, interpersonal and textual domains of meanings. However, unlike any other form of functional grammar analysis, the current study does not perform parsing of clauses as it does not help interpreting the analysis. Rather, mental parsing is done by means of which to derive at the three domains of meanings of the poem in order to arrive at the field, tenor and mode of the discourse. 


\section{RESULTS AND DISCUSSION}

Interpersonally speaking, the title of the poem Do You Remember Our Love? is polarized in the sense that it is a question with 'yes' or 'no' answers. It is a plain question with the mood elements of [do - you], as the finite verb and subject (of the sentence). The non-finite verb of 'remember' is the predicator anticipating the complement 'our love'. There is no modality or modulation, thereby simply asking for information whether the other party to whom the question was asked still remember (their) love. Ideationally speaking, the verb 'remember' belongs to a mental verb process since no physical action is made to perform 'remember'. It is only in the mind of the speaker.

However, it is not easy to interpret that the question occurs in a dialogue. Contextually, the poem does not indicate any second person to answer the question. The poet keeps expressing the question without expecting an answer. In other words, such a question may be uttered in solitaire.

The poet launches a circumstantial adjunct 'Between our little fights and our giggles', to start the stanza. There is an emphasis on 'our little fights' and 'our little giggles' to show that in their love, there are also 'fights' but weakened by the word 'little' also encountered by the phrase 'little giggles' to show charms and happiness. The poet starts a question 'Do you remember that you were the first lips I touched?'. This is actually a rhetorical question which does not need any answer. The question is further strengthened the next three phrases, 'the first hand I held', 'the first one I care for' and 'the first one I ever loved.'

The final clause 'the first one I ever loved' indicates that things have gone. There is no more romantic relation between the poet and her counterpart (lover). The mental verb 'love' has been put into a finite-past, meaning no longer 'now'. This further highlights that the poet represents a girl who used to have a boyfriend, and now she is trying to create a flashback about their love-trying to recall the past memory.

As previously mentioned, the polarized question is a rhetorical question which does not require an answer. It is simply a peripheral to highlight in her flashback events. Again, she expresses her emotion in solitaire. It is also possible that the poem is a letter to her ex-boyfriend in the hope that he would remember and thereby share his feeling. This is supported by the next line 'The first time I did I knew there was something there.' to show that there was a seed of love from which to grow their love. The spark (of love), as the next line goes, was felt only when they were together. What is more, it was further emphasized that the poet claimed that it was her boyfriend's arms to be put around her waist, and that she was lifted to the air (by a her boyfriend for the first time). There was nothing else but happiness for the two.

The next five lines of the poem, the poet implied metaphors (her boyfriend as Romeo and she was herself Juliet) to indicate the tragedy of their love as shown in the next line 'Do you remember we weren't allowed to see each other.' Their love was forced to end. Yet, the line 'But still we made it happen.' clearly shows that they still managed to see each other by means of whatever strategies they might have used only to prove the power of love.

Then came another problem, they weren't allowed to talk; but again they managed to keep talking. The poet ignites her boyfriend's memory in a rhetorical question 'Do you remember when we happened you held me so 
tight?' They held each other so tightly like a two headed snake, so tightly as if it were only death which could set them apart. This is common in 'first love' which everyone may have realized that 'first love' lies deep despite the normal fact that it ended on the way while it was growing. Both felt that the world was going to its end-no more hope, helpless and restless.

It is clearly shown in the next five lines of how hard it was for them to keep or maintain united (We didn't want to let go). How their hearts broke into pieces is shown in the line 'Do you remember when I would look at you and just smile?' This is a mysterious smile that sends a bitter message saying "There is nothing we can do to keep our love. Shall we let it go, my love?" It was then they turned to God for a simple relief-'You gave thanks to God everyday since he put me in your life.' Finally, it was clearly stated that they had to end their each-other love as shown in 'Do you remember when it was over?' The fact is that their love was (made to be) over. Yet, it was disguised in the next happy-looking line 'We still cared for each other.'

'If it were a story', this was the climax-a broken love. What is next is simply a memory that lingers over as if their love were still everlasting. The line 'You told me you wished the best for me.' is a common sentence uttered by a man upon heart breaks with a woman. However, a woman may have taken it seriously as shown in the next line 'Do you remember that you were the first one I ever cried for.' This line justifies that it is hard for a woman to be parted from a man. It is of course logical to think that a woman may have another love-that is to her Dad. It is shown to the next line, 'Beside my daddy when he left me.' There is a big question 'what is meant by '... when he left me.' It is possible that her father has passed away or simply left in physical distance. No information is available; or it is simply a spontaneous comparison between boyfriend and daddy as they are both males.

The poet further stressed how significant it was to be in love with her boyfriend as shown in 'Do you remember we had something that nobody had?' This is difficult to interpret '...we had something that nobody had.' The phrase 'nobody' seems an exaggeration-nobody on earth or simply a flavored feeling. In other words, the poet claimed that it was only she that could have a true love. It was further strengthened in the next line, 'Something people looked for but didn't find.' which is actually an accentuation of the previous line.

The anti-climax of the poem can be identified in the following five lines. Again, the poet stressed that she highly praised her boyfriend as seen in 'You were the best I ever had.' And, it was followed by direct statement that her boyfriend was her first love. She created another imagery perception by means of three wishes produced in the second conditional sentences, implying contradiction to the real fact. The first wish was that she wanted to see the beautiful smile. It was something impossible since her boyfriend was already away from her. Secondly, she wished to be in her boyfriend's arms-which is another mission impossible.

The poem concludes in the three lines; The third wish the poet has was to have her boyfriend back to her life for the rest of life. She did not regret whatever it is because she is still in love with her boyfriend.It is an open conclusion with multi-interpretational perspectives. One is that the poet is wildly in love with her boyfriend. She does not believe the fact that her boyfriend may have become a father to his children and a husband to his wife. 
It is a very dangerous situation. The poet, or it may apply to any female on earth, may have closed the chance to have another man as her spouse. She may stay single forever.

Another dangerous situation is that when she really meets her exboyfriend. Beautiful memories may return to their mind. They may repeat what they have done before-even more wildly. They simply fool around with each other. This normally starts with the man, telling that he is not happy with his wife and always wishes to return to the past memory. When the woman believes the man's made-up story, it all is about to begin-another love story, that may lead to illegal relationship and interpersonal problem. There is also another possibility in that the poet simply represents anyone on earth who is ever in love. Love repeats over times with or without different love stories.The poet simply wrote the poem just for fun without necessarily reflecting herself.

Functional Grammar (FG for short) has enjoyed its heyday over the last decades or so. It is a relatively new development in the analysis of language based on Halliday's work 'Systemic Functional Grammar' to analyze language in three dimensional meta-functions: Ideational, Interpersonal, and Textualthe three of which, simultaneously come up upon the production of linguistic texts. Others call them 'three domains of meanings'. It is commonly known that in the analysis of language in FG perspective, a text is analyzed in two ways of contexts: (1) context of culture and (2) context of culture.

The analysis of text based on the context of culture is similar to the one in the Analysis: Interpretational Perspective. Meanwhile, the analysis of text based on the context of situation is performed on three register variables (1) Field, (2) Tenor and (3) Mode, or in full normally stated as Field of the Discourse, Tenor of the Discourse and Mode of the discourse. In other words, the analysis is on discourse level-qualifying meaning as a unified whole. However, there are two approaches that can be used to analyze at discourse level, one is micro-approach and the other is macro approach.

In the micro approach, the text is segmented into main clauses and minor clauses in which later on, the clauses are analyzed in terms of the elements attributed to ideational, interpersonal and textual meanings. The ideational meaning deals with transitivity systems, namely how verb processes and participants are operated in the pivotal systemic system. Furthermore, interpersonal meaning deals with mood and residue of the clause within a text to investigate how language users interpersonally negotiate meaninginfluencing the language products, such as politeness, rhetorical strategies to try to concentrate on the language uses to investigate the interpersonal attributes. Finally, the mode of the discourse reflects how the text is interwoven from sentences to paragraphs; paragraphs to a full text. It mostly deals with the thematic progression to find out whether the text belong to formal or informal, spoken or written.

In the macro approach-which is used in the current study-a text will be viewed as a total entity in terms of the field of the discourse, the tenor of the discourse, and the mode of the discourse. However, before each of the register variables can be described, it is important to highlight some important points in the three meta-discourse (domains of meanings), namely ideational, interpersonal and textual. The field of the discourse is attributed to the 
ideational domain of meaning; while the tenor of the discourse is attributed to the ideational domain of meaning. Finally, the mode of the discourse is attributed to the textual domain of meaning

The poem starts with a minor clause 'Between our little fights and giggles' as a circumstantial adjunct, and also as part of the topical mood with a finite verb (do) and a subject (you), to indicate the present state of action. The transitivity system recognizes that the verb process for remember bears a mental process which can only be realized in our mind. The poet tries to bring to memory flashback '...that you were the first lips I touched. The verb 'touched' is a material process, that is a real action of touching the lips for the first time, including the first hand I held, the first one I cared for and the only one I ever loved. All of the finite verbs are in the past tense form to convince that they are all flashbacked through the major clause 'Do you remember...?' which is in the present state of action. These five lines are best to represent the orientation of the whole poem.

From this point, it is clear that the poem is about a flashback-for the poet herself while inviting her boyfriend represented by the reader(s). Each individual reader is therefore interpersonally positioned as the poet's boyfriend. In case of female readers, they may be positioned as the audience to observe the flashback of love affair of the poet with her boyfriend. There is one strong argument that the poet is a female, that is from the name of the poetKarina Del Campo (a female name) with a close interpersonal meaning represented in you (her boyfriend) and I (the poet).

The first line of the next five lines consists of three clauses, (a) Do you remember .... (b) you made me smile... and (c) when I first saw you. Clause (a) is the main clause, functioning as the starting point of the story upon orientation in the past five line. The finiteness of the mood 'Do you' represents an eternal truth as compared with the mood in minor clause (b) you made representing an event of the past as the beginning of 'love', strengthened by the mood of another minor clause (c) when I first saw. This line arouses the reader(s) supposed to be the poet's boyfriend to recall the past event when 'love' began. The second and third lines further elaborate what was going on in the love, first love. Line 4 is stressed using the same main clause 'Do you remember' plus the minor clause 'that you were the first to put your arms around my waist' and further elaborated in Line 5 'The first to lift me in the air' Functional grammarians shall call it 'clause extension'.

The above five lines of the poem may be literarily defined as 'rising action 1 ' when the love starts to grow between the poet and her boyfriend. It runs well for quite some time until the 'rising action 2' comes up which starts with the line 'You were my Romeo, I was your Juliet' as commonly known as 'forbidden love'. Line 2 strengthens the statement, employing the same mood 'Do you and predicator 'remember' with the main message located in a minor clause 'we weren't allowed to see each other'. The problem is, however, resolved in the next line 'But we still made it happen.' Another problem arouses, another solution comes up. The poet tries to force her boyfriend to recall how tight he hugged her to react to the problems of their love.

The next five lines function as further elaboration of how love between the two was really forbidden. The climax is that their love is over with the poet's claim to still care for each other.These five lines represent the climax of 
the poem which can be put in one line 'Despite the end of our love, we still love each other.' It is hard to indicate whether her boyfriend still cares for her since the poet keeps saying 'Do you remember...' It seems that her boyfriend ignores her.

The poet keeps hoping to be loyally united to her boyfriend as indicated in the following last lines. Line 1 and line 4 employ the mood element of 'Do you and a predicator 'remember'. This further strengthens the researchers' assumption that her boyfriend does not any more love her (the poet). In this poem, the poet tries very hard to convince her boyfriend how much she really loves him, and how much he really means to her. The last but one line 'To have you forever' is an elaborative clause extension of a clause 'The third would be to have you back in my life.' In despair, the poet closes the poem saying "Till this day you're still in my heart. And I don't regret a thing.

\section{CONCLUSION}

In general, the poem is good and contemporary in nature. It was written in response to a heartbreak of a young girl whose first love to her boyfriend was forbidden. The love broke apart on its blooming flavor. However, the girl expects the return of love, too much to say that she is still in love with her boyfriend. It is reflected in the style she employed, that is to ask him whether he still remembers the beautiful love stories made up together, just the two of them.

In functional grammar terms, the poem was ideationally developed with the use of clear nouns, adjectives, and circumstances to indicate that the field of the discourse is about love story' of two individual which, due to one thing or another, is forbidden. Nothing can be done to make them united. However, the boyfriend keeps encouraging the girl to be strong enough to face the reality. The girl is strong enough. She keeps hoping the return of love although it is a mission impossible.

Interpersonally speaking, the poet employs close relation between participants as indicated by the use of the personal pronouns 'I and You'. The finite verbs are the present to ignite the memory of his boyfriend, and the past to retell the past events of love. The boyfriend has been provoked to recall the past memory and to return his love to her. The poem ends in hope and expectation. The tenor of the discourse is therefore close, personal, social and informal. Even it can be said that the poem employs spoken language with a number of repetition of 'Do you remember...' when something new is introduced, either as a problem or a solution.

In terms of textuality, or textual meaning, the poem is developed in a regular interval of theme and rheme. The theme happens to be a major clause 'Do you remember...' It is followed by the rheme, consisting of past love events. One line supports or elaborates the previous line. In short, the poem is developed on a regular pattern, namely a major clause (Do you remember...) and minor clause(s) as the main event(s). Despite minor clauses as attached to the major clauses, there are also minor clauses in non-finite forms. Therefore, it is easy to understand the poem even for elementary students.

This study has yielded that functional grammar analytical framework, at a macro sense, can be used to unfold literary works of poetry genre. Therefore, it is recommended that: 
1) Poetry shall not be considered as a difficult subject since to analyze a poem does not-but it is better-necessarily makes use of complicated literary theories. In other words, linguistic theories (especially those of systemic functional linguistics) may be used to at least unfold the intended meanings (ideationally, interpersonally, and textually) of a particular poem.

2) Poems are said to reveal one's personal repertoire of mind, as found in the current study-a girl's expectation of the return of the past love. If beauty can be made used of in expressing one's feelings, why bother to express feelings in anger and desperation. The current study invites people to express feelings (of love or anger) in a beautiful way. It can be imagined how the poet under study was hurt when she was trying to express her feelings through a poem of her own. Still she was able to beautify her selfexpressions.

3) Everyone must try to write a poem when he or she is emotionally touched. The poem under study is very simple in both style and diction; yet, it can express what the poet feels. Poems can beautify the ugly and uninteresting issues, highlight important issues, and deny unrealistic fact in a favorable way without necessarily hurting other people's personal feelings.

\section{REFERENCES}

Ariadi, E. S. (2017). Discourse and third space in frank mccourt's novel“ teacher man" and tom schulman's play" dead poets society"; a reflective practice for teachers. EduLite: Journal of English Education, Literature and Culture, 2(2), 457-469.

Campo, K. Del. (2009). Do You Remember Our Love? Retrieved from https://www.familyfriendpoems.com/poem/do-you-remember-our-love

Electricka.com, T. (n.d.). How To Approach A Poem. Retrieved from http:/ /electricka.com/ETAF/muses/literature/literary_forms / poetry/how _to_approach_a_poem/how_to_approach_a_poem.htm

Fadhillah. (2017). Sejarah Bahasa Inggris Sebagai Bahasa Asing di Indonesia. Retrieved February 9, 2017, from https://manusiasuper.wordpress.com/2011/06/09/sejarahinggrisindone sia

Halliday, M. A. K., Matthiessen, C., \& Halliday, M. (2014). An introduction to functional grammar. Routledge.

Ho, W. K., \& Wong, R. (2000). Language policies and language education: The impact in East Asian countries in the next decade. Marshall Cavendish Intl.

Idris, T. (2014). Language Policy and the Construction of national and Ethnic Identities in Indonesia. US-China Education Review B, 4(10), 691-705.

Liana, L., Andraini, F., \& Mariana, N. (2016). Incubation of creative industry and information technology business based on stikubank university (case study of sbs incubator stikubank university). Proceeding ICOBAME.

Paauw, S. (2009). One land, one nation, one language: An analysis of Indonesia's national language policy. University of Rochester Working Papers in the Language Sciences, 5(1), 2-16. 
EduLite Journal of English Education, Literature, and Culture

Vol.3, No.2, August 2018, pp. 161-172

E-ISSN: 2528-4479, P-ISSN: 2477-5304

http://jurnal.unissula.ac.id/index.php/edulite

DOI: http://dx.doi.org/10.30659/e.3.2.161-172

Purwanto, S. (2017a). Grammar matters: A study of free writing performance of the sixth semester students, FBIB-UNISBANK. Jurnal Ilmiah Dinamika Bahasa Dan Budaya, 12(2), 10-17.

Purwanto, S. (2017b). Tess Gallagher's the hug: What is it out there? Jurnal Ilmiah Dinamika Bahasa Dan Budaya, 12(1), 18-31.

Simanjuntak, R. R. (2009). Bahasa Indonesia: Policy, Implementation, and Planning. Lingua Cultura, 3(1), 11-19.

Suharsimi, A. (2006). Prosedur penelitian suatu pendekatan praktik. Jakarta: Rineka Cipta. 